The following conclusions may be drawn from the results obtained in these experiments:

(1) The percentage of corn-ear worm and mold injury decreases as the number of dustings are increased.

(2) The cost of dusting is prohibitive where corn is grown for grain or forage but is practical where corn is raised for roasting ears, show purposes, or for seed corn.

(3) Sulphur is superior to flour or lime as a carrier for arsenate of lead and there is some indication that it also serves as a fungicide.

(4) Fifty per cent arsenate of lead does not control the corn-ear worm as effectively as does 75 per cent arsenate of lead.

\title{
A NEW SPECIES OF ISOSOMA ATTACKING WHEAT IN UTAH ${ }^{1}$
}

By R. W. Doane, Stanford University

During the past two summers, while carrying on certain investigations in Utah, for the American Smelting and Refining Co., Department of Agricultural Investigations, I have had an opportunity to study the life-history and habits of different wheat-infesting Isosoma, and to note something of the effect of their work in the wheat fields.

In the so-called dry farm regions in Salt Lake Valley it is a common custom to plant wheat every other year, letting the fields lie fallow during the alternate years. Often, however, the fields are not plowed during the year that they are supposed to lie fallow, but are allowed to grow a volunteer crop which is sometimes more or less profitable. The plowing that is done at any time is usually with a disc plow and a large part of the straw and stubble is left on the surface of the ground.

It will at once be seen that such farm practices offer almost ideal conditions for the development of stem-infesting wheat pests, and it is not surprising to find the Isosomas doing an immense amount of injury there, sometimes reducing the crop yield to a small proportion of what it normally would be.

My attention was first called to these pests when I found the adults in considerable numbers in a field of winter wheat in May, 1914. Two species were collected at this time. One proved to be the well known wheat straw worm, Isosoma grande, the other species, as far as I can determine, is undescribed. Because the larvæ confine their attacks to the leaf-sheath, I have called the species Isosoma naginicolum,

${ }^{1}$ Contribution from the Laboratories of the American Smelting and Refining Co., Department of Agricultural Investigations. 

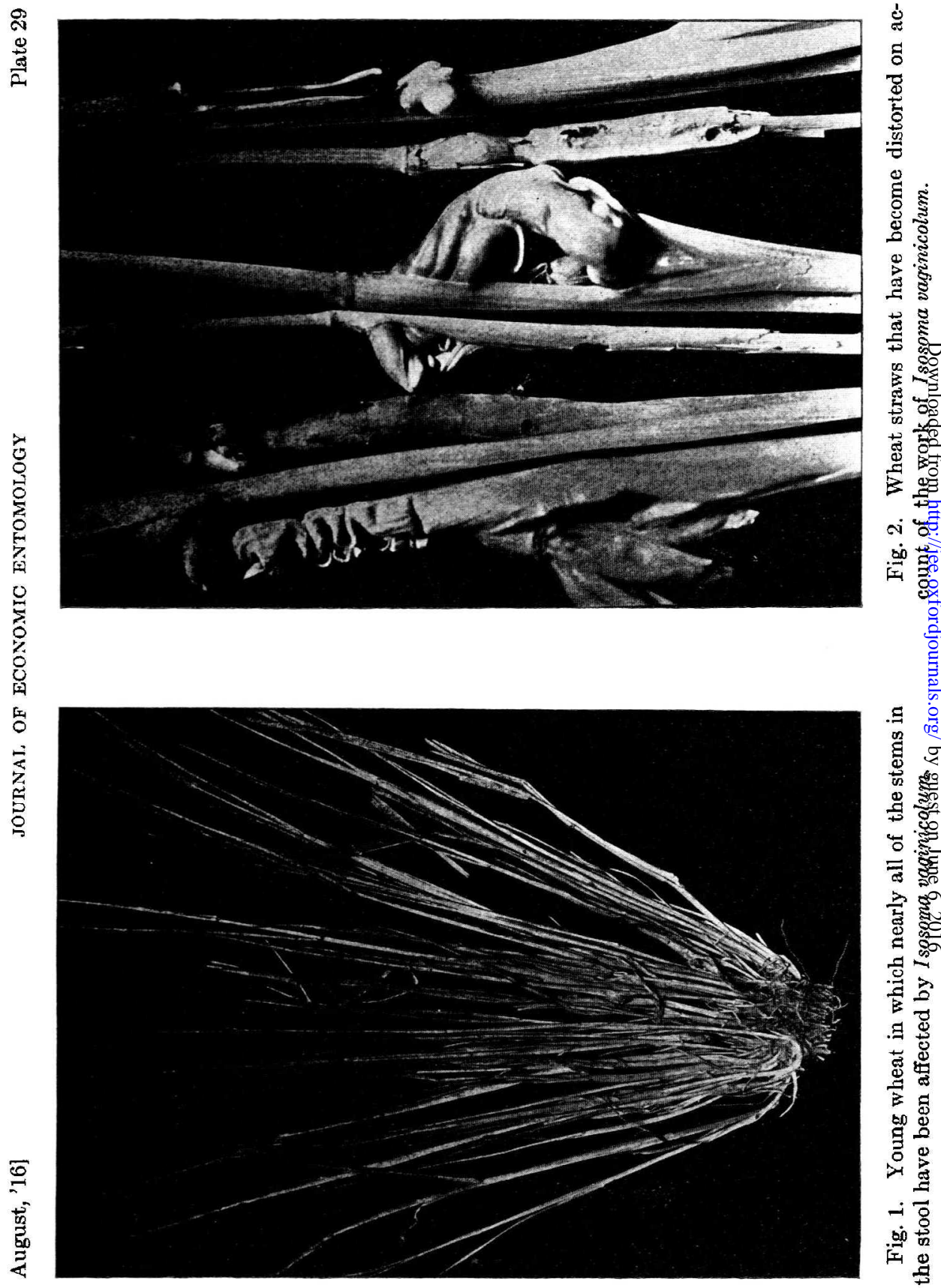
and have used the common name of "the wheat sheath worm." brief description follows:

\section{Isosoma vaginicolum n. sp.}

Head, wholly opaque black, finely punctate, with fine white pile; antenne black, basal segments faintly yellowish, especially below, the club somewhat shorter than the three preceding segments taken together, thorax black, finely punctate, in certain lights a faint yellowish spot may be seen on the anterior lateral corner of the prothorax; coxe and trochanters black; femorac of the first pair of legs black at base, yellowish toward the tip, in some instances nearly all of the distal half, especially below, is yellowish; femora of other legs black, yellowish at tip; anterior tibiæ yellowish, sometimes somewhat darker, especially below; other tibix blackish, yellowish at base and tip; tarsi yellow, last segment darker at tip; wings reaching to the tip of the abdomen; abdomen shining black, extreme tip (ovipositor sheath) yellowish; length $3 \mathrm{~mm}$.; wing expanse $5 \frac{1}{2} \mathrm{~mm}$. to $6 \mathrm{~mm}$.

Isosoma grande, which is found in the same fields as $I$. vaginicolum, may easily be distinguished from the latter species by its large size and shining thorax. A few specimens of $I$. tritici were also found in this region. They may be distinguished from $I$. vaginicolum by the basal segment of the antennæ being wholly black and the club being

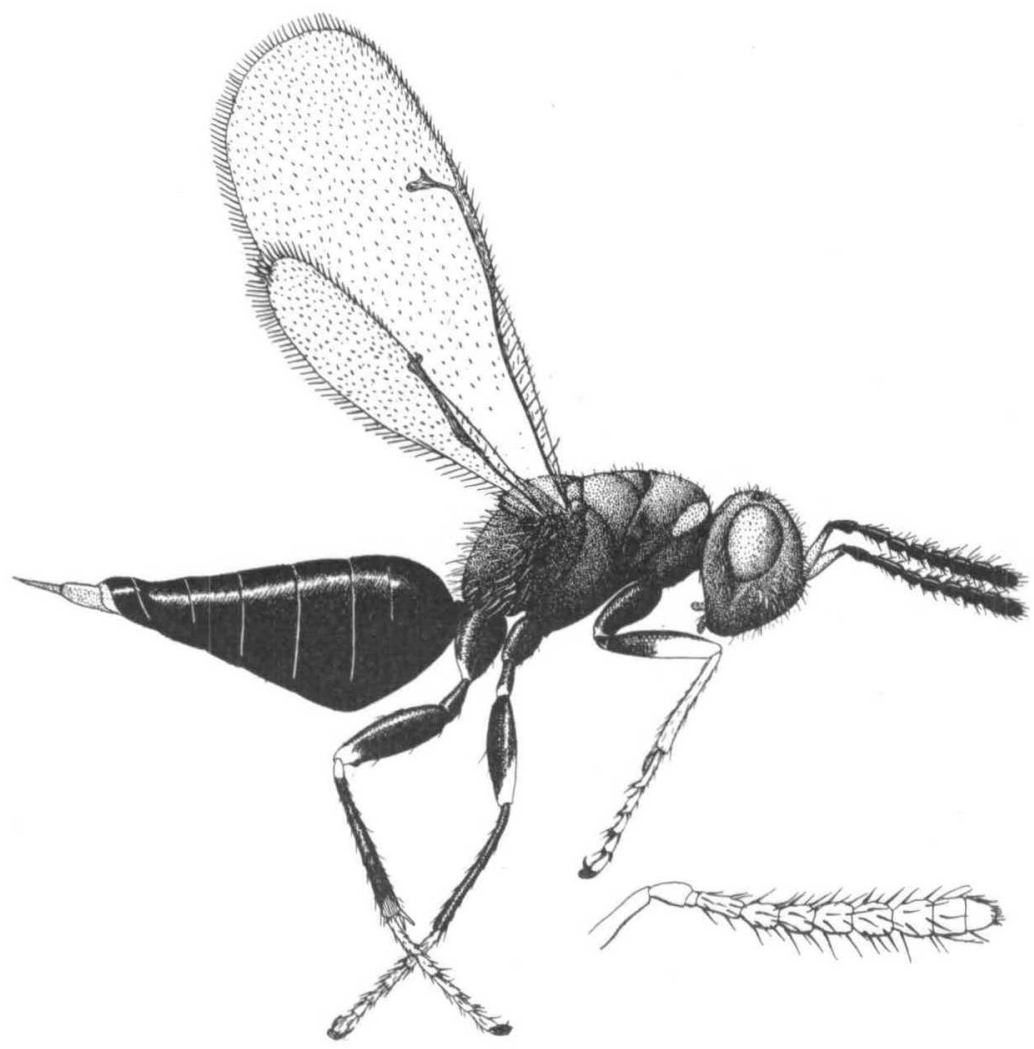

Fig. 23. Isosoma vaginicolum. 
as long or longer than the three preceding segments taken together. The face of $I$, tritici is somewhat longer and the abdomen broader posteriorly, that is it is not quite as tapering as in I. vaginicolum.

Most of the adults of $I$. raginicolum appear during the month of May. At this time they may be found laying their eggs in the base of the leaf-sheath just above one of the joints, usually near the middle of the stem. Three or four or often as many as fifteen or twenty eggs may be laid close together and when the larva begin to develop the leaf-sheath becomes more or less swollen. Each larva is enclosed in a firm little oval cell from a quarter of an inch to three eighths of an inch long. The swelling and hardening of the walls of the sheath presses on the stem in such a way as to prevent the sap from flowing through it readily and the plants become stunted and produce only small, poorly-developed heals. If the plants are badly affected or if they are infested early, they may produce no heads at all or the heads may never develop far enough to burst from the protecting leaf-sheath. In some fields eighty to ninety per cent of the wheat stems are infested and the crop loss will amount to from fifty to seventy-five per cent. I have seen some fields so baclly injured that they were not considered worth the harvesting and the whole crop was a total loss. If the larval cells are rey and the stem becomes much distorted. These swollen and distorted stems resemble very much the stems that have been injured by $I$. tritici, but a "areful examination will show that the cells occur only in the leaf-sheath, whereas the larva of $I$. tritici are found in the walls of the stem of the plant.

The larve remain in the stems throughout the summer, fall and winter, and pupate in their cells during $A$ pril and May. Most of the adults issue in May and early June.

I have found Isosoma raginicolum only in the dry farm region. $I$. grande, which occurs with it there, has a much wider distribution, being found commonly in the wheat fields in the irrigated districts as well. In the well-tilled, well- irrigated fields, however, the injury that the wheat straw worm does is not as important or noticeable as it is in the dry farm regions, where the loss of the young plants duc to the work of the first generation of larve, and the hardened thickened walls of the stems, due to the presence of the summer brood of larvæ, affects very seriously the quantity and quality of the yield of wheat. The effect of the work of this insect in the wheat fields in this state is similar to the conditions described by Webster and Reeves in Circular 106 of Burcau of Entomology.

I have found, both in Ctah and California, that if a very young plant is attacked by the larve of the second gencration it may be 
destroyed or made to stool excessively, the effect being the same as produced by the work of the first generation of larva in the earlier wheat.

A little later, but still early, infestation with $I$. grande affects the height and size of the stem and the size of the head, usually making the head small or very small. An early infestation of the highest or next to highest joint affects the size of the head but does not appreciably affect the height of the stem. Infestation of the third joint docs not seem to affect the plant as seriously as infestations higher or lower made at approximately the same time. A very late infestation may occur in one or even in two or three joints without seriously affecting the stem or the head.

\section{NOTES ON RHOGAS TERMINALIS CRESS.}

(Hymenoptera, Braconida)

By W. E. Pennington, Scientific Assistant, Cereal and Forage Insect Investigations ${ }^{1}$

During the summer and fall of 1914 a very severe outbreak of $C$ irphis (Heliophila) unipuncta Haw. occurred at Hagerstown, Md. This outbreak was carefully investigated by the force of the United States Entomological Laboratory located at that point. Incidental to this work several parasites of the insect were reared. This paper deals with the data collected on one of these parasites, Rhogas terminalis Cress. (Fig. 24a), and is presented at this time because it throws a little additional light on the phenomenon of parthenogenesis.

During late September, October and early November, a large number of Cirphis unipuncta larve were collected from the ficld. These larva were isolated in tin salve boxes two inches in diameter and three quarters of an inch deep. As the larve were isolated, they were arranged by accession numbers which were marked with wax pencil on the top of the box. The cages were stored in galvanized iron trays (Pl. 30), were examined daily and fresh food supplied when necessary. In this way the clata was cxact from the time of collection of the original host to the completion of the experiment. From this material the initial series of Rhogas terminalis for the following experiments was obtained.

Table I gives the exact data relative to the emergence of the stock material.

The first note made at this Laboratory on Rhogas terminalis is dated August 7, 1914, on which date J. A. Hyslop collected nine adult fe-

'My thanks are due Mr. J. A. Hyslop for helptul suggestions and assistance in preparing the test and furnishing the illustrations; for the original adults making the experiments possible, and for the courtesies of full coöperation. 